RESEARCH PAPER

\title{
Smoking, disease, and obdurate denial: the Australian tobacco industry in the 1980s
}

\author{
S M Carter, S Chapman
}

Tobacco Control 2003;12(Suppl III):iii23-iii30

See end of article for authors' affiliations

......................

Correspondence to: Stacy M Carter, School of Public Health, Room 128A Building A27, University of Sydney NSW 2006 ,

Australia; carters@

health.usyd.edu.au
Objective: To contrast the Australian tobacco industry's awareness of the diseases caused by smoking with their aggressive public denial on the relation between smoking and disease in the 1980s.

Design: Analysis of 325 industry documents from the world wide web.

Results: In the 1980s Australian cigarette manufacturers were informed constantly by the international industry of the medical consensus that smoking caused disease. In addition Philip Morris (Australia) Limited received reports of Philip Morris' international biological research programme and visited its Richmond research facility; and WD\&HO Wills part funded, co-managed, and contributed research to the British American Tobacco groups' biological research programme. Despite this knowledge, the Australian manufacturers had a policy of arguing to their employees, decision makers, and the general public that questions of smoking and disease were unresolved. The industry catalogued the literature, developed arguments against the main claims made by health groups, and attacked public health advocates who made statements linking smoking to death and disease. Industry studies suggested that a $20-30 \%$ minority of the Australian public agreed with the industry on smoking and disease, diminishing across the decade. Conclusion: Australian manufacturers were clearly negligent in the 1980s, deliberately working to undermine Australians' understandings of the diseases caused by smoking despite their own private knowledge. Continuing scepticism about smoking and disease, corresponding with the industry's deceptions, exists in Australian smokers today, suggesting that their actions may have slowed the rate of decline in smoking prevalence. These revelations provide important evidence for Australian litigation and advocacy.
$\mathrm{T}$ he tobacco industry's responsibility to inform its current and future customers about the diseases caused by tobacco use is the most fundamental ethico-legal issue in tobacco control, central to questions of legal liability for sick smokers, and a vital underpinning for regulation of advertising, product labelling and other industry communications. The tobacco industry's own internal documents, made available through the US Master Settlement Agreement ${ }^{1}$ and whistleblowing, ${ }^{2}$ have revealed a half century history of deliberate industry denial on questions of smoking and disease, and a globally cooperative "smoker reassurance program". ${ }^{3}$

Publications supporting this conclusion focus on the US, ${ }^{24}$ German, ${ }^{5}$ and British ${ }^{2}{ }^{6}$ tobacco industries, and are relevant to Australia in that local manufacturers are all members of multinational corporate families. The companies concerned are Philip Morris International (PMI), which oversaw Philip Morris (Australia) Limited (PML); the British American Tobacco (BAT) Group, which had an Australian subsidiary, WD\&HO Wills (Wills); and to a lesser extent, RJ Reynolds, which operated in Australia primarily through distribution in the 1980s and had a small market share. There are few documents available regarding Rothmans of Pall Mall, the fourth company operating in Australia in the 1980s, because it was not involved in the US Master Settlement Agreement.

Because of these multinational relationships, the relevant published literature provides an international context for Australian document research. BAT had agreed privately from the late 1970s that smoking caused disease and that epidemiology was the appropriate discipline to investigate this relationship, in stark contrast to their public denials on both counts. ${ }^{2}$ Project Rio, a controversial BAT project "designed to organise the company's research on cigarettes having reduced biological activity" ${ }^{\prime 2}$ was active throughout the 1980s in the BAT laboratories in Hamburg, Montreal, and Southampton. ${ }^{2}$ Rio examined the mutagenicity of smoke, but produced more questions than answers, as well as legal anxiety about the potential US liability surrounding the scientific work of the larger BAT group. ${ }^{2}$

The US environment was very different. Although there had been private industry agreement since the 1950s that smoking caused disease, ${ }^{4}$ little biological research was done, by agreement, because of the risk of litigation. ${ }^{4}$ In fact, in 1970, RJ Reynolds was forced by other US tobacco companies to close its biological research programme, which was demonstrating that smoking caused disease. ${ }^{4}$ PMI employed an alternative strategy, outsourcing much of its controversial research to offshore laboratories, to prevent legal discovery and allow rapid termination of projects showing dangerous results. ${ }^{4}$

This paper is part of a project explicitly designed to document evidence useful for litigation and tobacco control advocacy in Australia. Australian tobacco companies have sought to distance themselves from research on international industry conduct, pleading ignorance or irrelevance. ${ }^{7}$ The Australian industry is assisted on this point by the lack of research on the conduct of the local industry on smoking and disease. In response, this paper will review the Australian tobacco industry's awareness of and conduct related to questions of smoking and disease in the 1980s, a decade in

Abbreviations: $\mathrm{ACCl}$, Australian Chamber of Commerce and Industry; BAT, British American Tobacco; CAC, Chairman's Advisory Conference (BAT); CORESTA, Cooperation Centre for Scientific Research Relative to Tobacco; GR\&DC, Group Research and Development Centre; PMI, Philip Morris International; PML, Philip Morris (Australia) Limited; SRG, scientific research group; TIA, Tobacco Institute of Australia 
which the Australian industry's communication strategies were particularly aggressive. The findings will be most relevant to smokers who were old enough to absorb media messages during the 1980s and early 1990s: smokers aged approximately 25 and over in 2003. Other papers in this supplement complement the findings reported here. ${ }^{8-12}$

\section{METHODS}

The data for this paper came from document sites on the world wide web arising from litigation in the USA. ${ }^{1}$ Documents came from the primary sites of the manufacturers, ${ }^{13}$ the Council for Tobacco Research ${ }^{14}$ and the US Tobacco Institute, ${ }^{15}$ and the secondary sites of Tobacco Documents Online (Bliley, BC, Health Canada and Guildford Miscellaneous collections), ${ }^{16}$ the Canadian Council for Tobacco Control, ${ }^{17}$ the British Columbia Ministry of Health Services, ${ }^{18}$ and the Centers for Disease Control and Prevention Guildford collection. ${ }^{19}$ The search string "pagewood or moorabbin or granville or australia or sydney or melbourne or brisbane or hobart or adelaide or perth or canberra or amatil or wills" has been used throughout the project to gather documents relating to the Australian market. Of those identified and annotated as revelatory throughout the course of the project, 320 were from the 1980s and related to the issue of smoking and disease causation. This paper presents only a subset of the evidence: all 320 documents are available from http:// tobacco.health.usyd.edu.au/site/gateway/docs/research.htm An overview of our approach to document searching and analysis is available elsewhere. ${ }^{20}$

\section{RESULTS}

\section{The industry's private knowledge}

The context

In March 1978, the global BAT group held its research and development conference in Sydney, Australia. The first paragraph of the minutes read:

\section{"there has been no change in the scientific basis for the case against smoking. Additional evidence of smoke-dose related incidence of some diseases associated with smoking has been published. But generally this has long ceased to be an area for scientific controversy." 21}

By the 1980s authoritative public health pronouncements on smoking and lung cancer were more than two decades old, and the Australian industry was aware of the international consensus. Information was distributed to the local industry by the Tobacco Institute of Australia (TIA), and by INFOTAB, the international tobacco industry's information management organisation. ${ }^{8}$ Shook Hardy and Bacon, (the industry's outside legal counsel in Kansas) and BATCo had "data banks ... capable of keeping the industry abreast of developments on smoking issues," which the Australian industry could access. ${ }^{22}$ Australian manufacturers also attended joint industry activities such as CORESTA meetings. ${ }^{23}$

Any contention that the local Australian industry was ignorant of the 1980s literature on smoking and disease is thus unsustainable. Further documentation of the flow of information into the Australian industry is available at http:// tobacco.health.usyd.edu.au/site/gateway/docs/research.htm.

Research done by the tobacco industry

The manufacturers did not rely solely on external research. RJ Reynolds developed bioassays for testing the tumourigenicity of their products, ${ }^{24}$ produced critiques of unfavourable research, ${ }^{25}$ commissioned reviews of the published literature, ${ }^{26}$ and cultivated links to university departments. ${ }^{27}$ It is highly likely that this work was communicated to RJR in Australia, but no "smoking gun" to prove this has been found in the documents. There is, however, evidence linking PML and Wills to the disease research undertaken by their parent companies.

\section{Philip Morris research}

In the 1980s, the Philip Morris Corporation's in-house research facilities employed eight staff to critique published research and 80 in animal laboratories and cutting edge, cellular level research facilities in Richmond (USA), Cologne (Germany), and Neuchatel (Switzerland). ${ }^{28}$ Applied product development was emphasised, including work towards low biological activity products. Richmond and Neuchatel provided research support to global companies such as PML. Basic research information from external sources such as the published literature, universities, and biotech companies was organised by PM USA in a confidential database. The PMI corporate affairs department collected "up-to-date smoking and health related information" and circulated it to offices including PML in Australia. ${ }^{29-31}$ PML undertook product development research in its Australian headquarters at Moorabbin, ${ }^{32}{ }^{33}$ liaised with PM's overseas R\&D units and received copies of their reports, including reports on biological testing, ${ }^{34}{ }^{35}$ and made visits to the central research facility in Richmond. ${ }^{36}$

\section{Wills research}

The disease effects of smoking were foremost in the minds of Wills' managers, evidenced by their labelling all corporate affairs reports "Smoking and health," whether these addressed taxation, advertising, or social acceptability issues. ${ }^{37}$ The BAT Group was connected by a GR\&DC (Group Research and Development Centre) team, an international network of researchers which exchanged information via a programme of regular meetings, correspondence, and visits. ${ }^{38-43}$ Wills was a relatively small player in the group, with a local focus. ${ }^{44}$ Nonetheless Australia was considered one of BAT's six "Major R\&D Centres". ${ }^{44}$ Wills was also a "CAC company", that is, one of the companies which sent representatives to the BAT Chairman's Advisory Conference, and thus an active participant in decision making.

The search for a "safer" cigarette and Project Rio In 1980, BAT executives still hoped that the company's problems could be solved by the production of a "safer" cigarette. To this end, BAT was engaged in a million pound a year biological research programme. This programme had two arms. The first was concerned with developing tests of mutagenicity, biochemistry, and inhalation which would yield rapid results. ${ }^{45}$ The second was the much larger Project Rio. Rio investigated the biological effects of smoke, and aimed to produce an "acceptable" cigarette which could be demonstrated to lower cancer risk and thus give BAT a marketing edge. ${ }^{46}{ }^{47}$ Wills contributed to Rio but also understood its potential dangers, recommending to the BAT GR\&DC in 1983:

\section{"A program has to be developed to handle Project Rio... This general area is an important one for the long term survival of the industry and as such we support it. About $12 \%$ of the research effort goes into this area. (It is the second largest area). We would feel this effort is large but reasonable." 48}

The same year CAC companies like Wills were instructed to concentrate on applied product and process research rather 
than basic research. ${ }^{49}$ Wills' responsibilities within Rio were reduced to the testing of local commercially successful cigarette brands for their "relative mutagenicity". ${ }^{46} 49$ Wills evaluated Hallmark, Marlboro, Benson and Hedges, and Winfield, and found that a Wills "low tar" brand, Hallmark, was the cigarette with the highest mutagenic activity-an unfortunately common finding which was discussed at BAT Group meetings and in reports. ${ }^{39} 4650$

\section{Legal restructure of BAT research}

Understandably, the group became anxious to distance itself from "dubious past research", leading to a major restructure of Rio and direct lawyer involvement in "every step" of BAT's smoking and disease activities. ${ }^{49}{ }^{51}$ By 1985, the "commercial aspects" of Project Rio were pronounced complete, and reports prepared for individual participating CAC companies such as Wills. ${ }^{50} 52$ Southampton used Rio data to draw conclusions about correlates of mutagenicity in BAT cigarette designs worldwide, concluding that features such as filter ventilation, still common in "light" Australian cigarettes, increased mutagenicity across BAT brands. ${ }^{49} 5253$

For legal reasons, the drive to restructure BAT research intensified throughout 1985. The CAC laboratories were considered too "independent" and "inconsistent", and Wills were instructed to clear any BATCo documents "dealing with scientific and other potentially controversial issues" through the groups' lawyers before release. ${ }^{44}{ }^{54-57}$ In 1985 a new groupwide "research rationale" distinguished "product research (to be done internally) [from] smoking and health research (to be done externally) in future". Basic research was further de-emphasised. ${ }^{44} 58$

\section{The scientific research group to monitor external research}

"External" work to "determine the health consequences, if any, of smoking to the smoker" was monitored by a new scientific research group (SRG.) The SRG was established in April 1986, with representatives from CAC companies, to advise BAT companies on the product development and policy implications of external research work. ${ }^{58} 59$ Although Wills objected to paying an equal share of the costs of SRG activities relative to other CAC companies, Wills contributed tens of thousands of pounds to SRG monitored work. Wills also attended some SRG meetings. ${ }^{59} 60$

SRG members (including Wills) were conscious of their responsibilities. In 1986 they noted: "current [legal] opinion indicates a clear duty to be aware of relevant scientific literature on smoke and health issues, and, if necessary, to carry out appropriate research on the product and/or its effects on the smoker." ${ }^{\prime 59}$ The SRG reviewed the literature, identified gaps, commissioned and monitored external research, directed group companies on R\&D issues, and met to hear presentations of the results of commissioned research. Presentations were generally on topics favourable to the industry such as the benefits of nicotine, and thus provided the SRG with "good news". ${ }^{61}{ }^{62}$

\section{Wills' internal product research}

From 1985 internal product research, focusing on potential regulatory challenges like measuring smoke toxicology, was reviewed to increase international coordination, quality, and reporting. ${ }^{58} 6364$ Southampton "maintain[ed] a knowledge base on factors influencing specific constituents" and "provide[d] background on the opportunities for removing specific constituents". The role of operating companies such as Wills was to "develop products with reductions in specific constituents" to capture health concerned smokers in a shrinking market. ${ }^{64} 65$
Wills remained a relatively minor player in the global research team ${ }^{66}$ but continued to study Australian smokers under the internal research programme. In 1986 "a relationship was established" between Wills and the Southampton GR\&DC, "in which equipment for monitoring human smoking patterns was supplied [to Wills] to support the research programme on smoke quality. Data collected [were] transferred instantaneously to R\&D [Southampton, from Sydney] for duplication of smoking behaviour and determination of smoke component deliveries." ${ }^{63}$ Wills also contributed financially to the centralised GR\&DC research programme, although their contribution was smaller due to their relatively lower volume of cigarette sales. ${ }^{67} 68$

\section{The BAT research programme winds down}

As the 1980s wound down so did the BAT research effort: in 1989 the Southampton laboratory staff was slashed from 500

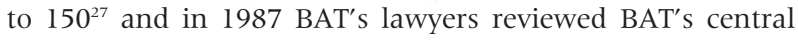
R\&D files containing decades of work, a confidential exercise intended to be protected by legal professional privilege and not disclosed to third parties by R\&D staff. ${ }^{68}$ Allegations that BAT engaged in systematic document destruction in Australia to protect themselves from legal action have been made both in the courts and by whistleblowers in the media. ${ }^{69} 70$

\section{The industry's communications}

Internal strategies on smoking and disease

The early 1980s was a time of "definite change in the attitudes of the [international] industry, [from].... generally passive stance to an active approach on smoking issues" ${ }^{\prime 1}$ This was prompted by the realisation that their two decades of relative silence on smoking and disease were eroding industry credibility. ${ }^{72}{ }^{73}$ Australian manufacturers were no exception to this change. PML's corporate affairs department set out to "minimise the impact of unfavourable events arising from the smoking and health ...controversy" via a range of PR strategies including the use of political, advertising, and journalism contacts. ${ }^{30}$ Wills characterised the Australian industry as having a "policy", as follows:

\section{"advocat[ing] strongly its right to do business in the market place, that the question of whether people smoke or not is a function of individual adult choice from a range of lifestyle options (of which smoking is merely one) and that further research is needed to help resolve the unresolved questions surrounding smoking and its possible relationship to human health. ${ }^{1 / 37}$}

The 1980s through to the early 1990s was a unique period of intense, aggressive, obdurate denial, in the face of the industry's aforementioned private agreement that smoking caused illness.

In the 1980s, employees and affiliates at all levels were indoctrinated with the official policy: that disease causation was still an unresolved question..$^{75}$ There are many examples of internal communications defending smoking. A 1985 document from PML Legal Department files dismissed specific disease claims as unscientific. ${ }^{76}$ At a 1986 Annual General Meeting PML exhorted shareholders:

\footnotetext{
"the company does not accept that there is overwhelming scientific and medical evidence indicting cigarette smoking as the largest cause of preventable death and disease in Australia... a significant body of eminent medical and scientific opinion does not hold that view... the true causes of the illnesses remain unknown... the tobacco industry in
} 
Australia has, through the Australian Tobacco Research Foundation, supported over 100 independently conducted medical research projects in Australian universities and teaching hospitals."

At a 1984 meeting of the board of BAT Industries, major shareholder in Wills' parent company AMATIL, directors were instructed:

\begin{abstract}
"[this year] more anomalies have come to light to support the controversy on causation... despite 30 years of intensive research, no compound or group of compounds in cigarette smoke have been identified as having a causal link... As in the past, the only recourse for the industry is to undertake or support more research... possibly during the next five years and almost certainly within 15 years... smoking and health issues will be resolved, one way or the other." ${ }^{\prime \prime 8}$
\end{abstract}

Into the late 1980s, BAT's meetings of its regional and national managers featured "scientific" presentations that denigrated "statistics", highlighted apparent epidemiological anomalies, and rehearsed analogies that undermined the

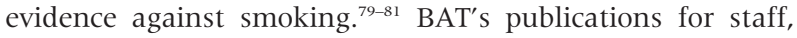
distributed to Wills, included a booklet promoting low tar cigarettes and the company's research investment, a massive "Issues guide" for corporate affairs management, and the detailed "Compendium of epidemiological studies," a three volume work for scientists highlighting the "controversy". ${ }^{81-85}$

Internal conflict on smoking and disease

There is extensive documentation of turmoil within the BAT group on the nature of their public stance. In 1980 LCF Blackman, BAT's head of research in the UK, felt that:

\begin{abstract}
"other companies or industry associations...are...tending to over-state the causation is not proven argument which we believe will not convince any audience-and will probably further reduce rather than raise the credibility of the Industry. ${ }^{\prime \prime 86} 87$
\end{abstract}

BAT's public affairs, legal department, and R\&D personnel worked for a whole year to find "ways of breaking out of the dilemma without prejudicing the legal position [of the industry]". ${ }^{86}$ This resulted in a proposal for a "new approach of open communication". The proposal was that BAT should "acknowledge (but...not accept) the strong body of opinion that smoking is associated with risk" and should promote their development of reduced risk products. ${ }^{86}$

However, the presence of an American company (Brown \& Williamson) in the BAT group raised the spectre of US legal liabilities and Blackman's advice was quashed. ${ }^{86} 88$ Wills opposed Blackman's position, at least in part because "parts of Dr Blackman's paper would appear to conflict with the propositions Widdup [Managing Director and Chairman of AMATIL] put to the Senate Committee [Inquiry into tobacco] five years [before]". ${ }^{89}$ Questions of product liability were not to become a serious threat in Australia until the end of the decade..$^{90}$

\section{Communications beyond the industry}

Australian manufacturers, individually and through the TIA, implemented the policy of misleading the Australian public on smoking and disease. This was done via publicly distributed newsletters, advertising and interviews in news media, self published books and pamphlets, medical conferences, and sympathetic publications such as the Australian
Retail Tobacconist. The misrepresentation of the state of medical research was deliberate. The TIA, in its informationmanagement role, sought out the tiny body of work that dissented from medical authority (for example, a TIA staffer's 1983 request to the US Tobacco Institute for "articles refuting the US Surgeon General's report or UK Royal College of Physicians report" $\left.{ }^{\prime \prime}\right)^{91}$ and then concentrated these ideas in user friendly form to promote to the public.

The Australian industry had scant regard for science when formulating these publications: in fact, twice during the 1980s even BAT was outraged by the inaccuracy of the Australians' claims. The TIA's 1983 pamphlet "The smoking and health controversy...why more research is needed", sent to parliamentarians, libraries, and tobacco employees, ${ }^{92}{ }^{93}$ was strongly criticised by BAT's researchers in Southampton. They called it unbalanced, simplistic, superficial, and unconvincing, noting that it conflated evidence and opinion and ignored the published literature. ${ }^{94}$

In 1985, the BAT Group were concerned about a Wills position paper which proposed that "people dying from smoking-associated disease do so at a later average age than those from non-smoking-associated diseases". ${ }^{9596}$ Their statistical consultant reviewed the paper and advised: "l am afraid that this paper is very naive statistically and the conclusions and implicit inferences to be drawn from them are in many cases unsound". ${ }^{97}$ He called it "deliberately antagonistic", and noted that the writer did not seem to understand the points that he or she was making. ${ }^{97}$

There are many examples of the Australian industry publicly contradicting the scientific consensus. The TIA published a press advertisement in the Australian Financial Review entitled "Smoking. Let's be sensible about it", ${ }^{98}$ which insisted that tobacco control advocates were "imply[ing] scientific certainty where none exist[ed]...[and] simplistically...blam[ing] cigarette smoking for various diseases and deaths". ${ }^{99}$ John Dollisson (TIA) stated in 1986:

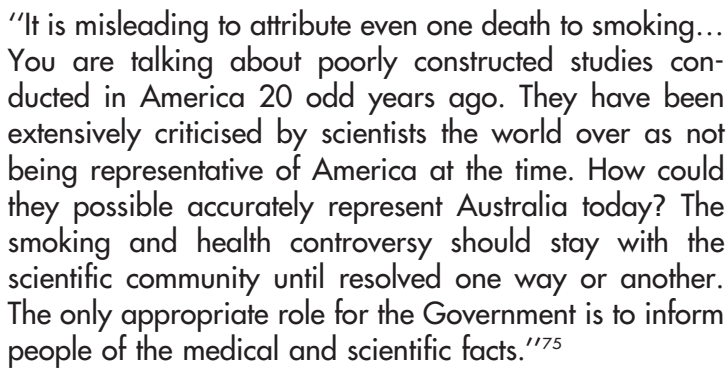

Geoff Bible, then managing director of PML, promoted the policy in a speech to journalists where he encouraged smokers in the room to "take heart [because] your lungs are as pink and pretty as those of the nonsmoker sitting next to you". Bible claimed that "thirty years ago, even twenty years, it was possible for an honest man to believe that smoking was the cause of all the ills that flesh is heir to". However, he argued, after spending \$100 million on research, the tobacco industry had not been able to find the "one ingredient" to blame that could be removed..$^{100}$

AMATIL (Wills) were not only true to the policy of claiming more research was needed in the 1980s, they were happy to publicly concede that the industry had jointly agreed to that position. Duncan Fairweather argued on Australian radio in 1984:

"our position on health is quite clear... we think there are
some questions to be raised about the statements that are
made by the medical authorities, in the meantime there's a
lot more research needed. That's a standard position that 


\section{the industry has adopted and everyone is well aware of it." ${ }^{\prime \prime 101}$}

Many other examples of the Australian industry's consistent and aggressive support of the policy are available from http://tobacco.health.usyd.edu.au/site/gateway/docs/research. htm, including a 30 minute radio sound file featuring John Dollisson, the head of the TIA, responding to radio listeners' questions in Sydney in 1984.

\section{Attacks on accurate information}

In addition to actively misleading Australians on disease, the industry opposed what it termed "anti-smoking propaganda". ${ }^{102}$ The industry instituted a "policy of vigilance against attacks by its opponents, while taking further constructive initiatives to place them on the defensive" ${ }^{\prime \prime}{ }^{103}$ Generally the industry's attacks demanded that messages be removed or demanded statistical or clinical substantiation of claims.

These actions were designed to intimidate health authorities, advocates, researchers, and editors and ultimately to deny Australian consumers access to accurate information. They were conducted by the TIA or its lawyers, Clayton Utz, were sometimes supported by Don Hoel of Shook Hardy and Bacon or by PML, and sometimes used third party strategy via advertising industry contacts. Public statements by individuals as well as government health promotion campaigns were targeted, directly and through regulatory bodies including the Advertising Standards Council, Federation of Australian Commercial Television Stations, Media Council of Australia, and the Australian equivalent of the US Federal Trade Commission, the Trade Practices Commission, which received a series of complaints alleging that consumers were being misled by statements on smoking and disease.

In some instances the industry's objectives were achieved: the offending messages were withdrawn by the self regulatory agency in question. ${ }^{104}$ The industry even considered taking action against advertisements for nicotine chewing gum ${ }^{105}$ and in 1987 attacked the Medical Journal of Australia regarding the content of published research articles, ${ }^{106}$ a paradox considering the industry's continuing protestations about the need for continuing medical research. Further evidence of industry's monitoring of tobacco control and counter-attacks is available at http://tobacco.health.usyd. edu.au/site/gateway/docs/research.htm.

\section{Impact on public opinion}

Throughout the 1980s the TIA continually monitored changes in public opinion about smoking. ${ }^{107}$ Despite their efforts, opinion from 1983 to 1990 showed changes unfavourable to the industry:

- "smoking is bad for you even if you smoke only a few a day": increase in agreement from $75 \%$ to $83 \%$

- "the medical profession is correct in everything it says about smoking being a cause of lung cancer, heart disease and other health problems": $75 \%$ to $80 \%$ agreement

- "the medical profession has exaggerated the risks of smoking": decrease in agreement from $28 \%$ to $21 \%$

- "smoking helps some people handle situations in which they experience stress": decrease from $72 \%$ to $63 \%$

- "people are sufficiently aware of health concerns and further government sponsored anti-smoking and health advertising would be a waste of public money": $40 \%$ to $45 \%$ agreement

- "people should be constantly reminded that smoking is harmful": consistent agreement around 80\%
These results demonstrate that the industry's aggressive public communications did not change majority public opinion. They also show that the industry enjoyed continued support of a diminishing minority of Australians on most issues, a minority which may in fact have consisted of smokers seeking reassurance.

\section{DISCUSSION}

We have provided evidence that, in the 1980s, Australian cigarette manufacturers were continuously made aware of the international consensus on smoking and disease via both the TIA and their parent companies. Australian executives attended meetings where the diseases caused by tobacco were openly discussed, and had the research literature digested and delivered to them. PML was informed on PM's international biological research programme and visited PM's Richmond research facility. Wills helped fund and manage the BAT biological research programme, tested the mutagenicity of Australian cigarettes before such activity stopped in 1985, and continued to study human smoking patterns and smoke component deliveries in Australian smokers beyond 1985 .

Despite this knowledge, the Australian manufacturers' policy throughout the 1980s was to argue that the question of a relation between smoking and disease was unresolved and to advocate their "right" to do business and smokers' "right" to smoke. Internal and external communications conformed to this policy. Considerable resources were devoted to cataloguing the research literature, which overwhelmingly implicated tobacco as disease causing. Further resources were then committed to designing formal responses which sought to deny the case that had built against tobacco. So eager was the Australian industry to deny the disease effects of tobacco that at times BAT contended that they did not understand the science of their product. The industry also attacked public health advocates making statements on the relationship between smoking and disease.

It is clear to any layperson that these are morally unjustifiable acts. They are also unjustifiable even by the standards of the tobacco industry's own culture: business. The Australian Chamber of Commerce and Industry (ACCI) is the peak council of Australian business associations, and the conservative voice of business in Australia. The industry's actions clearly defy the ACCI policy on consumer protection, which states that "consumers ...have the right to expect... safety standards from goods and services purchased [and] protection from misleading and deceiving practices...". ${ }^{108}$ Given the extent and deliberateness of the industry's activities, it seems appropriate that the executives, the directors, and the lawyers employed by Wills and PML from the 1980s and early 1990s should be investigated with respect to their possible liability under Australian law.

It may be that the industry's efforts were not highly effective in the general community. Nigel Gray, Australia's leading tobacco control advocate in the 1980s, has characterised the industry as largely ineffectual in public debates, ${ }^{*}$ and the lacklustre results of the industry's public opinion polls support his views. Newspaper editorials advocating for continued tobacco advertising at the time frequently qualified their arguments by stating that smoking certainly caused disease. The Advertising Age editorialised in 1983 that "the industry's credibility began its nose dive when Phil Scanlon, a spokesman for the major Australian tobacco company AMATIL Ltd., said on national TV that the tobacco industry believed smoking did not constitute a health risk" and noted that "the reaction against the ad [Smoking: Lets

*Gray N. Interview. Personal communication to Chapman S, Carter S, Bryan-Jones K: Sydney, 29 November 2002. 
be sensible about it] was enormous. Federal and State health ministers condemned the industry's attempts to deny that 16,000 Australian die every year due to smoking-related diseases and questioned the misleading presentation."109 According to an advertising industry spokesperson "Smoking: Lets be sensible about it" was a "poorly conceived and executed non-event" which did the industry more harm than good. ${ }^{109}$

However, when the TIA's Brian Gapes defended the production of the "Let's be sensible about it" advertisement, he claimed "a lot of smokers applauded our action". ${ }^{109}$ In 1984, Andrew Whist of PMI wrote with regard to Australia that "antismoking propaganda" was starting to persuade "even smokers" that it was an "undesirable habit". ${ }^{110}$ This is an important distinction, particularly given that the industry knew that committed smokers were more likely to support them on crucial policy issues. John Dollisson (TIA) argued in 1986 at an international workshop: "Smokers and nonsmokers are not homogeneous groups when responding to industry issues. The stronger the smoker's commitment to smoking the stronger their support on issues."111

The main objective of the industry's aggressive communication on smoking and disease may have been to maintain the trust of smokers already predisposed towards the industry's position, thus providing their consumers with reasons to doubt the "anti-smoking propaganda". Australian smokers are more likely than non-smokers to agree with statements like "the medical evidence that smoking causes cancer is not convincing" or "many people who smoke live to a ripe old age, so smoking is not all that bad for you", ${ }^{112}{ }^{113}$ positions constantly reiterated by the industry throughout the 1980s. The industry's opinion poll data suggested that a slowly decreasing minority continued to agree with their views in a decade when Australian male smoking prevalence reduced from $40 \%$ to $30 \%$, and women's from $30 \%$ to $25 \%$.

It seems probable that a diminishing cohort of committed smokers were responsible for the diminishing 20-30\% of agreement with the industry in their population based opinion polls. Industry advocacy may have allayed smoker's latent concerns, provided seemingly plausible rationalising life rafts, and ultimately, reassured them in their decisions to keep smoking. Today's sick and dying smokers, without any advanced epidemiological knowledge or skills in the critical appraisal of evidence, who now say "I heard lots of doctors and professors on the radio saying that there was actually no proof that smoking caused cancer" cannot be deemed to be simply ignorant or ill informed. A natural policy outcome of this work, then, is that smokers who were the recipients of the industry's policy of obdurate denial deserve to know the truth, not only about the disease effects of smoking, but about the efforts of the industry to deny these effects in the 1980s. Smokers have a right to access the information presented here, ideally via a mass media public information campaign.

The industry's cynicism towards smokers became apparent in the 1990s, as product liability litigation in Australia became a serious cause for concern. Overnight, the industry stopped arguing that there was no proof that smokers were at risk, and instead advised smokers that they should have listened to the public health authorities, and the responsibility for their illness was theirs. The industry's primary motivation in Australia in the 1980s, as ever, was not the pursuit of truth or science, or the wellbeing of its customers, but its own financial survival. Despite privately accepting that the case for smoking causing disease had long been established, the industry vigorously denied this via its public affairs activities. The revelations we have summarised provide important evidence for litigation by smokers exposed

\section{What this paper adds}

The historic conduct of the tobacco industry in seeking to mislead and reassure smokers about smoking and disease has been documented for the USA, Germany, and the UK.

This paper sets out evidence of the Australian industry's knowledge and conduct including internal research on smoking and disease, knowledge of external research, and misinformation supplied to employees, boards, decision makers, and the general public, including Australian smokers. This material will be useful in Australian litigation and advocacy.

to such industry campaigns, and for advocacy against industry mendacity.

\section{ACKNOWLEDGEMENTS}

Thanks to reviewers for helpful comments and Fiona Byrne for indispensable information management. The research reported in this paper was supported by grants from the National Health and Medical Research Council (2001-2003 \#153857) and the US National Institutes of Health (2001-2005 \# R01 CA87110-01Al).

\section{Authors' affiliations}

S M Carter, S Chapman*, School of Public Health, University of Sydney, Sydney, Australia

*Also Associate Director, VicHealth Centre for Tobacco Control

\section{REFERENCES}

1 Malone RE, eds. Tobacco industry documents: treasure trove or quagmire? Tobacco Control 2000;9:334-8.

2 Glantz SA, Slade J, Bero LA, et al. eds. The cigarette papers. Berkeley: University of California Press, 1996

3 Francey N, Chapman S. "Operation Berkshire": the international tobacco companies' conspiracy. BMJ 2000;321:371-4.

4 Ciresi MV, Walburn RB, Sutton TD. Decades of deceit: document discovery in the Minnesota tobacco litigation. William Mitchell Law Review 1999:25:477-566.

5 Hirschhorn N. Shameful science: four decades of the German tobacco industry's hidden research on smoking and health. Tobacco Control 2000;9:242-247.

6 Action on Smoking and Health UK. ASH UK website. http:// www.ash.org.uk/. (Accessed 29 Apr 2003)

7 Harris T. US smokes not like ours. Weekend Australian (Sydney) 12 Jul 1997:7.

8 Carter SM. Cooperation and control: the Tobacco Institute of Australia. Tobacco Control 2003;12(suppl III):iii54-60.

9 Chapman S, Carter SM, Peters M. "A deep fragrance of academia": the Australian Tobacco Research Foundation. Tobacco Control 2003;12(suppl III):iii38-44.

10 Chapman S, Carter SM. "Avoid health warnings on all tobacco products for just as long as we can": a history of Australian tobacco industry efforts to avoid, delay and dilute health warnings on cigarettes. Tobacco Control 2003;12(suppl III):iii 13-22.

11 Chapman S. "We are anxious to remain anonymous": the use of third party scientific and medical consultants by the Australian tobacco industry, 1969 to 1979. Tobacco Control 2003;12(suppl III):iii31-37.

12 Chapman S. "It is possible he is a kind of nut": how the tobacco industry quietly promoted Dr William Whitby. Tobacco Control 2003;12(suppl III):iii4-6.

13 Tobacco manufacturers' document websites. http://www.pmdocs.combin/rsasearch.asp; http://www.bw.aalatg.com/public.asp; http:// www.lorillarddocs.com/cgi-bin/rsasearch.asp; http://www.rirtdocs.com/ rirtdocs/index.wmt? tab $=$ home

14 Council for Tobacco Research document website. http://www.ctr-usa.org/ $\mathrm{ctr} /$ index. wmt? tab = home

15 Tobacco Institute document website. http://www.tobaccoinstitute.com/cgibin/Rsasearch.asp

16 Tobacco Documents Online. Smokescreen Corporation. http:// tobaccodocuments.org/

17 Canadian Council for Tobacco Control, tobacco documents site. http:// www.ncth.ca/Guildford.nsf

18 British Columbia Ministry of Health Services, tobacco documents site. http://www.moh.hnet.bc.ca/cgi-bin/guildford_search.cgi

19 Centers for Disease Control and Prevention, Guildford tobacco documents site. http://www.cdc.gov/tobacco/industrydocs/index.htm 
20 Chapman S, Byrne F, Carter SM. Australia is one of the darkest markets in the world": the global importance of Australian tobacco control. Tobacco Control 2003;12(suppl III):iiil-3.

21 Green SJ. Notes on Group Research \& Development Conference Sydney, March 1978. 6 Apr 1978. Philip Morris. Bates No. 2050987449/7455. http://legacy.library.ucsf.edu/tid/oac62e00

22 Blackman LCF. Smoking and health data bank. 20 Nov 1981. British American Tobacco. Bates No. 100431064/1168. http:// tobaccodocuments.org/health_canada/2195.html (Accessed 7 Apr 2003)

23 CORESTA. CORESTA technology group list of attendance. 27 Oct 1986. Philip Morris. Bates No. 2028459031/9033. http:// legacy library ucsf.edu/tid/qda24e00

24 Scott JK. Metabolic cooperation and tumor promotion. 14 Jan 1983. R.J. Reynolds. Bates No. 506312927/2959. http://legacy.library.ucsf.edu/tid/ izp74d00

25 Colby FG. RJR Weekly highlights. 3 Nov 1982. R.J. Reynolds. Bates No. $510750114 / 0116$. http://legacy.library.ucsf.edu/tid/hnv53d00

26 Johnson JD, Houchens DP, Kluwe WM, et al. Battelle Memorial Institute. The effects of mainstream and sidestream tobacco smoke on the immune system in animals and humans [RJR funded research review]. 1989. R.J. Reynolds. Bates No. 507053133/3234. http://legacy.library.ucsf.edu/tid/ qio34d00

27 Philip Morris USA R\&D Department. Strategic plan, 1989-1993. 1 Feb 1989. Philip Morris. Bates No. 2021556671/6874. http:// legacy.library.ucsf.edu/tid/ail71fo0

28 Colby FG, Rodgman A. Biological/consumer preference research conducted by Philip Morris. Mar 1983. Lorillard. Bates No. 98288733/8781. http:// legacy.library.ucsf.edu/tid/jidy54c00

29 Philip Morris USA. [Confidential database of published biological research]. 1989. Philip Morris. Bates No. 2050800012/0092. http:// legacy.library.ucsf.edu/tid/bip45e00

30 Philip Morris International. 1980 corporate affairs [annual report]. 1980. Philip Morris. Bates No. 2048129267/9296. http:// legacy.library.ucsf.edu/tid/rbr42d00

31 Bockman RH. Smoking issues 'Quick reference guide', second edition. 11 Aug 1980. Philip Morris. Bates No. 2025011016/1017. http:// legacy.library.ucsf.edu/tid/vsz46e00

32 Tobacco International, CORESTA, RJ Reynolds Tobacco Co., RJ Reynolds Tobacco International. CORESTA 1982 Symposium Program. 1982. Philip Morris. Bates No. 2050213189/3291. http://legacy.library.ucsf.edu/tid/ kho26e00

33 Philip Morris Corporation. [Research and development: organisational charts]. 1 Jul 1988. Philip Morris. Bates No. 2050971301/1324. http:// legacy.library.ucsf.edu/tid/pyy45e00

34 Philip Morris Europe R\&D Neuchatel. Final Report Project Slow/77-C1 Chemical and Biological Testing of Prototype Cigarettes $72-\mathrm{Cl}$ and $77-\mathrm{Cl}$. 10 Jan 1986. Philip Morris. Bates No. 2504077180/7204. http:// legacy.library.ucsf.edu/tid/jpi29e00

35 Philip Morris (Australia) Limited. [List of PML R\&D plans]. Feb 1985. Philip Morris. Bates No. 2504077214. http://legacy.library.ucsf.edu/tid/ kzn32e00

36 Harmsma O. [Memo to PM USA Richmond staff re: visit of Messrs Courtnay Ansley, Sean O Flynn and Henry Goldberg.]. 2 Nov 1983. Philip Morris. Bates No. 2074867797/7799. http://legacy.library.ucsf.edu/tid/ nnv17d00

37 Wills D. Smoking and Health Report Australia, June 1980 - Sept 1981. Sep 1981. Brown \& Williamson. Bates No. 690838842/8851. http:// legacy.library.ucsf.edu/tid/vgo90f00

38 Blackman LCF. Research Conference 1981 - Pichlarn, Austria. 27 Jul 1981. British American Tobacco. Bates No. 401099075/9076. http:// tobaccodocuments.org/health_canada/40109907.html (Accessed 7 Apr 2003)

39 Joint R\&D/marketing conference. 11 Apr 1984. British American Tobacco. Bates No. 100571363/1425. http://tobaccodocuments.org/ health_canada/10057136.html (Accessed 7 Apr 2003)

40 Gaisch H. Monthly report June: highlights June 1984. 29 Jun 1984. Philip Morris. Bates No. 2505485791/5794. http://legacy.library.ucsf.edu/tid/ fnb05c00

41 Heard AL. [Letter re: group research programme and conference]. $29 \mathrm{Apr}$ 1985. British American Tobacco. Bates No. 109882400. http:// tobaccodocuments.org/bc_moh/12824.html (Accessed 7 Apr 2003)

42 Felton DG. [Group Research and Development Centre memo]. 28 Mar 1980. British American Tobacco. Bates No. 103482628. http:// tobaccodocuments.org/bc_moh/31 158.html (Accessed 2 Apr 2003)

43 Thornton RE. [Letter to R.G.Nicholls].18 Dec 1985. British American Tobacco. Bates No. 107334943. http://tobaccodocuments.org/ health_canada/R1525_49.html (Accessed 15 Apr 2003)

44 British American Tobacco Co. Ltd. Marketing management programme: strategic product aspects, 1 Dec 1986. British American Tobacco. Bates No. 403624789/4964. http://tobaccodocuments.org/health_canada/ R1679.html (Accessed 15 Apr 2003)

45 British American Tobacco Co. Ltd. Research and Development Department. GR\&DC Research Program and Resource Allocation. 1 Nov 1984. British American Tobacco. Bates No. 100507203/7333. http:// tobaccodocuments.org/bat_cdc/25804.html (Accessed 3 Apr 2003)

46 British American Tobacco Co. Ltd. Biological Conference Southampton 911 th April 1984. 1984. British American Tobacco. Bates No. 100453480/ 3688. http://tobaccodocuments.org/bc_moh/11729.html (Accessed 7 Apr 2003)
47 British American Tobacco Co. Ltd. [Notes from 1981 research conference] 1981. British American Tobacco. Bates No. 110082167/2217. http:// tobaccodocuments.org/bc_moh/13108.html (Accessed 7 Apr 2003)

48 Hardwick MJ. Comments by CAC Countries on GR\&DC Work Programme Work Area 01: Biological. 6 Jul 1983. British American Tobacco. Bates No. 107471 165/1 166. http://tobaccodocuments.org/health_canada/ 03700695.html (Accessed 7 Apr 2003)

49 Blackman LCF. Research Conference Rio de Janeiro Brazil 22-26 August 1983. 13 Oct 1983. British American Tobacco. Bates No. 109882435/ 2458. http://tobaccodocuments.org/bc_moh/12830.html (Accessed 7 Apr 2003)

50 British American Tobacco Co. Ltd. GR\&DC Research Programme status review notes covering the period November 1984-April 1985. Apr 1985. British American Tobacco. Bates No. 109973802/3877. http:// tobaccodocuments.org/bc_moh/13075.html (Accessed 7 Apr 2003)

51 Wells JK. File note: conference with BAT legal on US products liability litigation. 12 Jun 1984. British American Tobacco. Bates No. 521015673/ 5675. http://tobaccodocuments.org/ness/90.pdf (Accessed 7 Apr 2003).

52 Massey ED. Project Rio - Comparison of commercial cigarettes: influence of design features in mutagenicity as measured by the Ames Test - A Summary Report, 26 Jan 1987. British American Tobacco. Bates No. 400909754/ 9756. http://tobaccodocuments.org/bc_moh/10815.html (Accessed 15 Apr 2003)

53 British American Tobacco Co Ltd. [Presentation: Project RIO. Part of Biological Conference Southampton 9-11th April 1984] 1984. British American Tobacco. Bates No. 100132177/2220. http:// tobaccodocuments.org/bc_moh/30107.html (Accessed 7 Apr 2003)

54 Heard AL. Group Tobacco Research and Development: Notes on a CAC R\&D Meeting. 18 Sep 1985. British American Tobacco. Bates No. 107442665/2675. http://tobaccodocuments.org/health_canada/ 10744266. html (Accessed 7 Apr 2003)

55 British American Tobacco Co. Ltd. Restricted B.A.T. (U.K. and export) Limited Research and Development Centre 1987 Work Programme. 1987. British American Tobacco. Bates No. 400260056/0178. http:// tobaccodocuments.org/health_canada/40026005.html (Accessed 15 Apr 2003)

56 Heard AL. Technical Aspects of Smoking and Health (memo). 6 Jun 1985. British American Tobacco. Bates No. 107356412. http:// tobaccodocuments.org/bc_moh/12420.html (Accessed 7 Apr 2003)

57 Smith PB. [Memo to Pascal Ricketts, BAT Industries]. 14 Feb 1985. British American Tobacco. Bates No. 503113615 . http://tobaccodocuments.org/ health_canada/R1675_61.html (Accessed 18 Apr 2003)

58 Heard AL. Group Research and Development Conference held in Rio de Janeiro. 12-15 November 1985. 3 Dec 1985. British American Tobacco. Bates No. 109877910/7921. hitp://tobaccodocuments.org/bc_moh/ 12791. html (Accessed 8 Apr 2003)

59 British American Tobacco Co. Ltd. Scientific Research Group. Research policy group meeting: 4-5 September 1986. 5 Sep 1986. British American Tobacco. Bates No. 107356311/6315. http://tobaccodocuments.org/ bc_moh/12413.html (Accessed 15 Apr 2003)

60 Thornton RE. [Memo to Mr C Borloz]. 15 Jun 1988. British American Tobacco. Bates No. 401035726/5727. http://tobaccodocuments.org/ bc_moh/10633.html (Accessed 15 Apr 2003)

61 British American Tobacco Co. Ltd. Scientific Research Group. 2nd meeting of Scientific Research Group Montreal, August 6th-8th, 1986. 8 Aug 1986. British American Tobacco. Bates No. 107356294/6295. http:// tobaccodocuments.org/bc_moh/12411.html (Accessed 15 Apr 2003)

62 BAT (UK. \& Export) Ltd. Research \& Development Centre Southampton. Status review notes: period ending December 1989. Dec 1989. British American Tobacco. Bates No. 400459141/9202. http:// tobaccodocuments.org/health_canada/40045914.html (Accessed 15 Apr 2003)

63 British American Tobacco Co. Ltd. Work area 702: applied research and development: general (research work plan). 1986. British American Tobacco. Bates No. 102393663/3688. http://tobaccodocuments.org/ bc_moh/12322.html (Accessed 8 Apr 2003)

64 Heard AL. Research conference, Sydney. 5 Sep 1986. British American Tobacco. Bates No. 107356297/6310. http://tobaccodocuments.org/ bc moh/12412.html (Accessed 8 Apr 2003)

65 Heard AL. Research policy group meeting. 28 Sep 1989. British American Tobacco. Bates No. 401034784/4795. http://tobaccodocuments.org/ bc_moh/10487.html (Accessed 15 Apr 2003)

66 Heard AL. Research policy group - briefing notes. 15 Sept 1987. British American Tobacco. Bates No. 401034583/4613. http:// tobaccodocuments.org/health_canada/40103461.html (Accessed 15 Apr 2003)

67 Salter R. Tobacco strategy review team. 23 Oct 1986. British American Tobacco. Bates No. 502378855/8859. http://tobaccodocuments.org/ bc_moh/11474.html (Accessed 15 Apr 2003)

68 Heard AL. Document Review. 3 Nov 1987. British American Tobacco. Bates No. 401034506/4507. http://tobaccodocuments.org/health_canada/ 40103453.html (Accessed 15 Apr 2003)

69 Chapman S. Tobacco Control Super Site: Law resources. The University of Sydney 2003. http://tobacco.health.usyd.edu.au/site/supersite/resources/ docs/reference law.htm (Accessed 19 Apr 2003)

70 Birnbauer W. The smoking gun, the insider, and the ghost of Rolah McCabe. The Age (Melbourne) 19 July 2003;1.

71 Covington M. Report on INFOTAB progress and plans. 3 Nov 1981. R.J. Reynolds. Bates No. 504331013/1025. http://legacy.library.ucsf.edu/tid/ ysg58d00 
72 INFOTAB. Draft report to the board of INFOTAB on credibility. 6 Jul 1983. British American Tobacco. Bates No. $301124369 / 4375$. http:// tobaccodocuments.org/bc_moh/12123.html (Accessed 18 Apr 2003)

73 Philip Morris International. The perspective of PM International on smoking and health issues. 29 Mar 1985. Philip Morris. Bates No. 2023268329/ 8337. http://legacy.library.ucsf.edu/tid/nky74e00

74 The Tobacco Network. Smoking and health. 1981. R.J. Reynolds. Bates No. 506642455/2459. http://legacy.library.ucsf.edu/tid/xvv44d00

75 Tobacco Institute of Australia. Casebook arguments. May 1986 May. Philip Morris. Bates No. 2501456347/6356. http://legacy.library.ucsf.edu/tid/ clu22e00

76 Philip Morris (Australia) Limited Legal Department [inferred]. "Smoking causes lung cancer". May 1985. Philip Morris. Bates No. 2504100405/ 0417. http://legacy.library.ucsf.edu/tid/esi29e00

77 Philip Morris (Australia) Limited. [Response to question at AGM]. Feb 1986 Philip Morris. Bates No. 2504100560. http://legacy.library.ucsf.edu/tid/ ytn $32 \mathrm{e} 00$

78 British American Tobacco Co. Ltd. Tobacco Strategy Review Team. Talk on smoking and health to the BAT Industries Board. 6 Mar 1984. British American Tobacco. Bates No. 301124550/7561. http:// tobaccodocuments.org/guildford_misc/301127550-7571.html (Accessed 18 Apr 2003)

79 British American Tobacco Co. Ltd. Scientific Research Group. Hamburg May 25-27 1987. minutes of SRG meeting. 27 May 1987. British American Tobacco. Bates No. 401024587/4592. http://tobaccodocuments.org/ bc moh/10636.html (Accessed 15 Apr 2003)

80 British American Tobacco Co. Ltd. Group Conference on Smoking Issues. 29 Mar 1988. British American Tobacco. Bates No. 401048516/8557 http://tobaccodocuments.org/health_canada/1934_001.html (Accessed 29 Apr 2003)

81 Ely RLO, Thornton RE. Group Conference on Smoking Issues. 29 Mar 1988 26 Jul 1988. British American Tobacco. Bates No. $401048605 / 8607$. http://tobaccodocuments.org/health_canada/1934_002.html (Accessed 18 Apr 2003)

82 BAT Group. Smoking and health: a BAT booklet for staff. 1980. British American Tobacco. Bates No. $301118389 / 8402$. http:// tobaccodocuments.org/bc_moh/11976.html (Accessed 18 Apr 2003)

83 Thornton RE. Compendium of Epidemiological Studies. Nov 1984. British American Tobacco. Bates No. 202202749/3002. http:// tobaccodocuments.org/bc_moh/31805.html (Accessed 18 Apr 2003)

84 British American Tobacco Co. Ltd. Note for the Tobacco Strategy Review Team Meeting. 2 Nov 1989. British American Tobacco. Bates No. 502621186. http://tobaccodocuments.org/bc_moh/11405.htm (Accessed 18 Apr 2003)

85 British American Tobacco Co. Ltd. Smoking issues: claims and responses. 1989. British American Tobacco. Bates No. 503102882/3097. http:// tobaccodocuments.org/bc moh/11511.html (Accessed 18 Apr 2003)

86 Blackman LCF. Stance on smoking and health: note for information and discussion. 18 Dec 1980. British American Tobacco. Bates No. 109881275/ 1278. http://tobacco.health.usyd.edu.au/tds/BAT109881275_1278 (Accessed 21 February 2003)

87 Blackman LCF. British American Tobacco. The credibility of the industry stance. 22 May 1980. Tobacco Institute. Bates No. TIOK0034611/4616. http://legacy.library.ucsf.edu/tid/whu91 foo

88 British American Tobacco Co. Ltd. Restricted British American Tobacco Co. Ltd. Management Board meeting. 18 Dec 1980. British American Tobacco. Bates No. 300053346/3351. http://tobaccodocuments.org/bc_moh/ 12179.html (Accessed 1 April 2003)

89 Baxter KP. [Letter to A. Holtzman]. 21 Jan 1982. Philip Morris. Bates No. 2024954710/4711. http://legacy.library.ucsf.edu/tid/efc46e00

90 Johnson A. Product liability litigation: briefing seminar in New Zealand. 23 Dec 1988. British American Tobacco. Bates No. $301165268 / 5269$ http:// tobaccodocuments.org/guildford_misc/301165262-5271.html (Accessed 19 April 2003)

91 Deegan C. Tobacco Institute of Australia. T.I. newsletter no. 346, 5.12.83. 14 Dec 1983. Tobacco Institute. Bates No. TIMN0149823. http:// legacy.library.ucsf.edu/tid/pyy $82 f 00$
92 Tobacco Institute of Australia. The smoking and health controversy... why more research is needed: a review of recent medical and scientific evidence presented to U. S. Congressional Committees. May 1983. R.J. Reynolds. Bates No. $503111915 / 1924$. http://legacy.library.ucsf.edu/tid/ xkk68d00

93 INFOTAB. Health and Science - Research/Communication [excerpt from INFOTOPICS]. 22 Aug 1983. R.J. Reynolds. Bates No. 504683039/3040. http://legacy.library.ucsf.edu/tid/fzp18c00

94 BAT Group Research \& Development Centre. Smoking issues literature review. Oct 1983. Brown \& Williamson. Bates No. 650371856/1889. http://legacy.library.ucsf.edu/tid/sqv1 4 fo0

95 AMATIL. Smoking and health. 16 Jan 1985. British American Tobacco. Bates No. 503113506/3519. http://tobaccodocuments.org/health_canada/ R1675_50.html (Accessed 7 April 2003)

96 Thornton RE. [Letter to Peter Lee] 7 Aug 1985. British American Tobacco. Bates No.107334676. http://tobaccodocuments.org/guildford_misc/ 107334676.html (Accessed 7 April 2003)

97 Lee PN. "Smoking and health": some comments on the draft paper prepared by AMATIL. 21 Aug 1985. British American Tobacco. Bates No.107334659/4663. http://tobaccodocuments.org/guildford_misc/ 107334659-4663.html (Accessed 7 April 2003)

98 Tobacco Institute of Australia. Smoking: let's be sensible about it. 1983 Philip Morris. Bates No. 2023084612. http://legacy.library.ucsf.edu/tid/ idn68e00

99 Advertising Standards Council smoking and health complaints. $10 \mathrm{Apr}$ 1983. Philip Morris. Bates No. 2024272377. http:// legacy.library.ucsf.edu/tid/fkl85e00

100 Bible G. The Freedom to Advertise. 27 Oct 1983. Philip Morris. Bates No. 2024272360/2372. http://legacy.library.ucsf.edu/tid/kkl85e00

101 Channel 7 State Affair Program. Interview between Howard Sattler, Peter Taylor \& Duncan Fairweather, Perth, 16 August 1984. 16 Aug 1984. Brown \& Williamson. Bates No. 690154616/4618. http:// legacy.library.ucsf.edu/tid/yhl02d00

102 WD\&HO Wills Corporate Affairs. Smoking and Health. Apr 1983. Brown \& Williamson. Bates No. 517001018/1022. http://legacy.library.ucsf.edu/ $\mathrm{tid} /$ jfb90fo0

103 Rule E. Smoking and health report, Australia, January - March 1982. 3 May 1982. Brown \& Williamson. Bates No. 690838785/8791. http:// legacy.library.ucsf.edu/tid/fgo90f00

104 McGrath M. [Telex to D. Hoel]. 3 Aug 1979. Philip Morris. Bates No. 2024978344. http://legacy.library.ucsf.edu/tid/zlx46e00

105 Browne C. INFOTAB. [Letter to J.Little]. $11 \mathrm{Jul}$ 1989. Tobacco Institute. Bates No. TIMN0314258/4260. hitp://legacy.library.ucsf.edu/tid/ syw52f00

106 Wilson B. Clayton Utz. Tobacco Institute of Australia Limited - Australian Medical Association and and Australasian Medical Publishing Company Limited. 6 May 1987. Philip Morris. Bates No.2504085941/5942. http:// legacy.library.ucsf.edu/tid//rn32e00

107 ACIL Economics and Policy Pty Ltd. The TIA smoking survey: summary of results, critique and options. June 1993. Philip Morris. Bates No. 2504079319/9354. http://legacy.library.ucsf.edu/tid/wev43e00

108 Australian Chamber of Commerce and Industry. Index to policies. 2003 http://www.acci.asn.au/index_policypapers.htm (Accessed 3 September 2003)

109 Powell R. Pressures are mounting to curb cigaret advertising down under. 12 Sep 1983. Brown \& Williamson. Bates No. 690108374/8375. http:// legacy.library.ucsf.edu/tid/thq01c00

110 Whist A. [Memo to R.W.Murray]. 17 Apr 1984. Philip Morris. Bates No. 20232731 19/3120. http://legacy.library.ucsf.edu/tid/uot24e00

111 INFOTAB. INFOTAB International Workshop, Brussels, Belgium, October 13-16, 1986. 16 Oct 1986. Philip Morris. Bates No. 2501446636/7080. http://legacy.library.ucsf.edu/tid/alr02a00

112 Chapman S, Wong WL, Smith W. Self-exempting beliefs about smoking and health: differences between smokers and ex-smokers. Am J Public Health 1993:83:215-19.

113 Oakes W, Chapman S, Borland R, et al. Bulletproof skeptics in life's jungle: which self-exempting beliefs about smoking most predict lack of intention to quit? Sydney: University of Sydney, 2003 (forthcoming). 